\title{
Corrigendum: Perceptions of Cultured Meat Among Youth and Messaging Strategies
}

\section{OPEN ACCESS}

Edited and reviewed by:

Mark Andrew Lawrence,

Deakin University, Australia

*Correspondence:

Gary J. Pickering

gpickering@brocku.ca

Specialty section:

This article was submitted to

Nutrition and Sustainable Diets,

a section of the journal

Frontiers in Sustainable Food Systems

Received: 18 August 2020

Accepted: 20 August 2020

Published: 05 October 2020

Citation:

Ruzgys S and Pickering GJ (2020) Corrigendum: Perceptions of Cultured

Meat Among Youth and Messaging

Strategies.

Front. Sustain. Food Syst. 4:596233.

doi: 10.3389/fsufs.2020.596233

\section{Shannon Ruzgys ${ }^{1}$ and Gary J. Pickering ${ }^{1,2,3,4 *}$}

${ }^{1}$ Department of Psychology, Brock University, St. Catharines, ON, Canada, ${ }^{2}$ Department of Biological Sciences, Brock University, St. Catharines, ON, Canada, ${ }^{3}$ Environmental Sustainability Research Centre, Brock University, St. Catharines, ON Canada, ${ }^{4}$ Sustainability Research Centre, The University of the Sunshine Coast, Sippy Downs, QLD, Australia

Keywords: cultured meat, clean meat, naturalness, consumer acceptance, food disgust, framing, young adults

\section{A Corrigendum on}

Perceptions of Cultured Meat Among Youth and Messaging Strategies

by Ruzgys, S., and Pickering, G. J. (2020). Front. Sustain. Food Syst. 4:122. doi: $10.3389 /$ fsufs.2020.00122

In the original article, there was a mistake in Figure 3 as published. The incorrect figure was included. The corrected Figure 3 appears below.

The authors apologize for this error and state that this does not change the scientific conclusions of the article in any way. The original article has been updated.

Copyright (๑) 2020 Ruzgys and Pickering. This is an open-access article distributed under the terms of the Creative Commons Attribution License (CC BY). The use, distribution or reproduction in other forums is permitted, provided the original author(s) and the copyright owner(s) are credited and that the original publication in this journal is cited, in accordance with accepted academic practice. No use, distribution or reproduction is permitted which does not comply with these terms. 


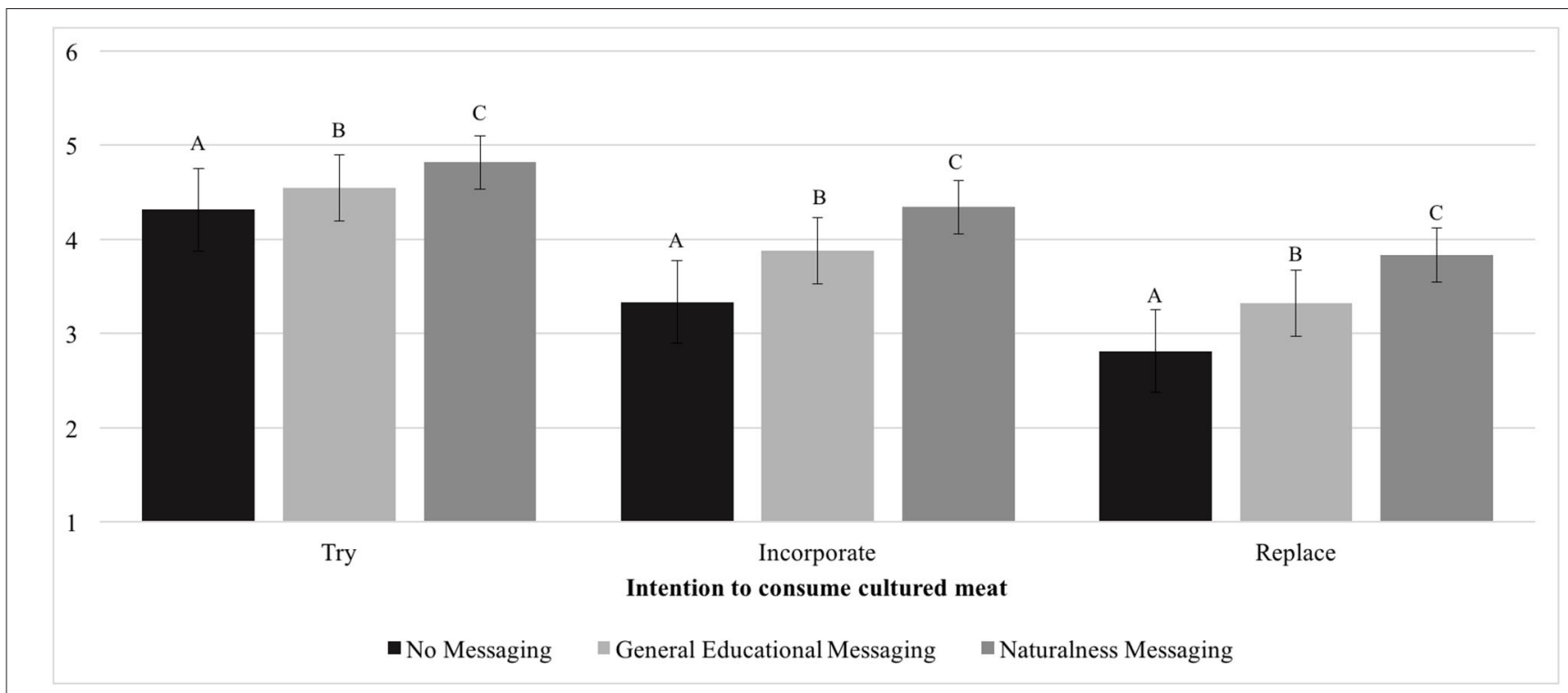

FIGURE 3 | Intention to try cultured meat, incorporate cultured meat into regular diet, and replace farmed meat/meat alternatives with cultured meat in regular diet across messaging treatments. Data shown are average responses from 7-point Likert scale (1 = "extremely unlikely" 7 = "extremely likely") \pm standard error. A, B, and C represent significant differences between the messaging treatments (Bonferroni 0.05 ). 